\title{
THE SECRET OF “CIRCLE” IN ISLAMIC ARCHITECTURE
}

\author{
Hossein Irani Sarand \\ M.Sc. of Architecture, Tabriz Branch, Islamic Azad University, Tabriz, Iran \\ atlaska200@gmail.com \\ Islamic Azad University, Tabriz, Iran \\ atlaska200@gmail.com \\ Mohammadreza Pakdel Fard \\ PhD, Department of Architecture, Tabriz Branch, Islamic Azad University, Tabriz, Iran \\ M.pakdelfard@srbiau.ac.ir \\ Akbar Abdollah zadeh Taraf \\ PhD, Department of Urbanism, Tabriz Branch, Islamic Azad University, Tabriz, Iran \\ Taraf1981@,iaut.ac.ir
}

\begin{abstract}
The Current study investigates the metaphorical properties and conceptual features of circler as one of the most significant geometric shapes in Islamic ornamentation as well as expression of its philosophical and symbolical aspects. Ornamentations in Islamic art and architecture covers the whole structure like a cloak, which aims at expressing unity, inspiring sacredness and eternity concept. Geometry is the key element of Islamic ornamentations and circle in this area has a high ranked position. In Islamic ideology, circle is the the only shape which symbolicaly can express the almighty God's magnefisence.Islamic architecture has always reminds the viewr to the center and birthpoint of universe and highness of devine. . By analysis and knowledge of inherent unique capabilities of circle and its other geometric forms, i.e. sphere, ring and arches, somehow a proper field has been created for targeted and wakeful usage of it by architects. Based on the holistic research approach, this paper follows theological argumentative procedure and it has been achieved by cultural- discursive system. This research reveals that it's the shape of circle which can solely afford the expression of concepts in Islamic philosophy such as pure magnificent of God and perfection, infinity and unity of the universe as well as light and the mystery in the world of symbols. Being converted from a geometric shape into artistic value, the circle is incorporated as a base for creation of ornamental geometric patterns and meaningful interlaced motifs and effects.
\end{abstract}

Keywords: Islamic architecture, circle, geometric patterns, philosophy of Islamic art, ornamentations.

\section{İSLAM MIMARİSINDE "ÇEMBER" SIRRI}

ÖZ

$\mathrm{Bu}$ çalışmada, benzetme özellikleri ve İslam süsleme sanatının yanı sıra düşünsel ve sembolik yönlerini ifade en önemli geometrik şekillerin olarak çemberin kavramsal özellikleri incelenmiştir. İslam sanatı ve mimarisi süslemeleri, birlikte kutsallığı ve sonsuzluk kavramını amaçlamaktadır. Geometrik yüksek sıralamalar İslami süslemelerinden ve bu alandaki dairenin kilit unsur durumundadır. İslam ideolojisinde, çember Yüce Allah'ın her zaman evrenin merkezinde olduğunu ifade eder. Bu araştırma yalnızca Tanrı'nın görkemli mükemmellik, sonsuzluk ve evrenin birliğini ışık ve semboller dünyasında gizem olarak İslam felsefesinin kavramlarının daire şekliyle ortaya koymaktadır. Sanatsal değeri bir geometrik şekle dönüştürülen daire süs geometrik desenler ve anlamlı geçmeli motifleri ve efektler yaratmak için kurulmuştur. 
Anahtar Kelimeler: İslam mimarisi, daire, geometrik desenler, İslam sanatının felsefesini, süslemeler

\section{INTRODUCTION}

Geometry and geometric proportions is one of beauty's effects that has seen in world's structure and diverse nature's effects. In other words, geometry is abstract essence of shapes that are existed in nature and enables traditional human to explore in nature in a more profound way. Geometry guides thankful mind from sensible to intellectual and from external to internal, reminding existence's transcendence.

Plato believes that geometry will be beneficial when compel the soul to pay attention toward truthful existence, but will not have any benefit for us if its effect is to draw attention of the soul to passing world and corruption and mentions:" God always deals with geometry." From his point of view, architecture and other technics in which measuring tools and equipment are used do gain more benefit from knowledge (Plato 2002, $3^{\text {rd }}$ volume: 13).

Geometry has turned to an art in Islam and dominated geometrical principals on material design. The variety of textures shows them harmonically (Ernest Grobe 2001 148). Abstract essence of Islamic art due to its effort to reflect imaginative universe has close correlation with semi abstractive essence of geometrical and mathematical sciences. Islamic geometric painting is considered as one of most controversial issues related to history of art and architecture. Unfortunately in the west, the Islamic abstract art of geometrical patterns and motifs, have always been considered as a type of mere ornamentation and decorative element, which is too far from the geometric patterns main message. (Kit krichlu 2011: 9)

Special potentials and characteristics that are hidden in different geographical shapes, make them ready for a mysterious and symbolic role and in other words square, triangle and circle are not mere shapes but also contains a fact inherently which its understanding through interpretation guides the human toward imaginal world and eventually toward truth (Ardalan and Bakhtiar 2002: 27). Now this question brings to mind that in what extent this fact regarding Islamic geometric is applicable in circle shape. On the other word, does circle in Islamic architecture have that kind of quality of morale and mystery that is stated for Islamic geometry? To answer this question we inevitably should answer to another implicit question related to different aspects of circle's application in Islamic architecture. Hence, we in coming sections of this research will explore for different practical and semantic aspects of circle in Islamic architecture in a way that get closer to position of geometry in Islamic architecture and its truth and also to focus on a subject that rarely is elaborated specifically.

In this respect, our discussion is a function of different opinions that is made regarding quality of geometry practice in architecture or generally Islamic art. With a glance on different opinions, we figure out clearly that followers of Khaledeh philosophy such as Rene Genon, Titus Burkehart and Kate krichlu had high success in understanding of meanings and mysterious aspects of geometry in Islamic architecture that some of these opinions would be implied within coming discussions.
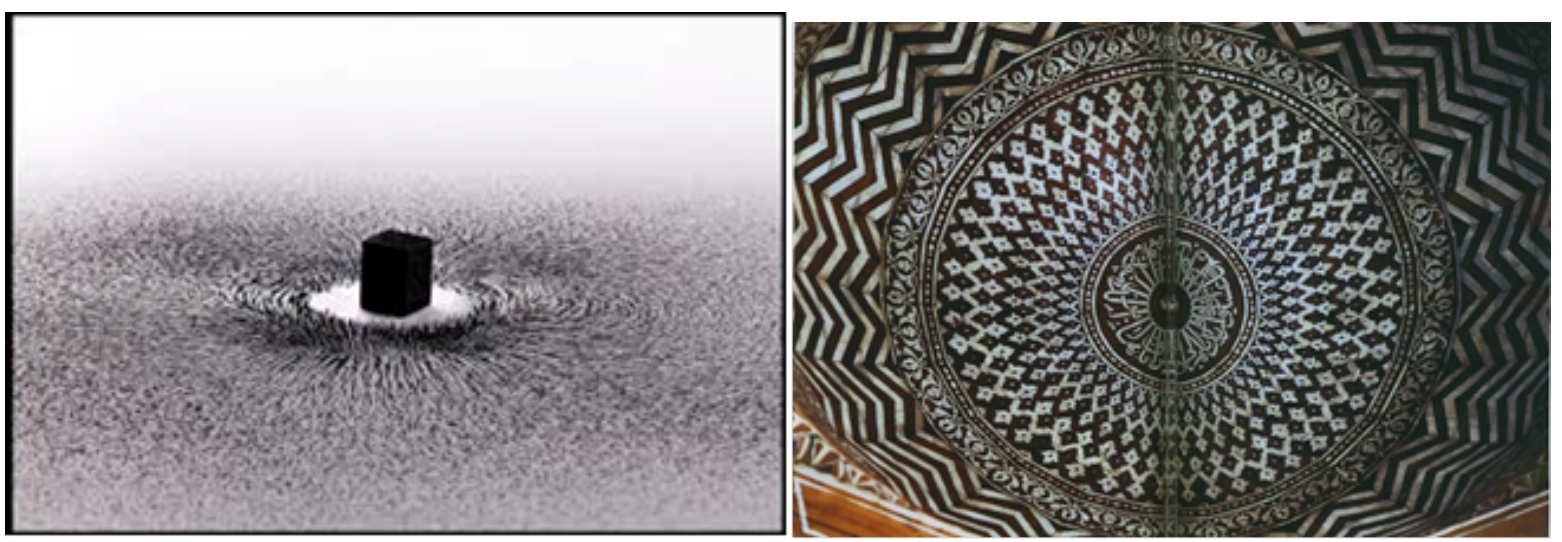
Figure 1: The Muslims spinning around the sacred Ka'ba which is the concept of Islamic circular ornamentation

\section{RESEARCH METHODOLOGY}

The research approach follows answering the questions based on the logical reasoning strategy within the cultural-verbal trends. Thus circle is investigated as one of the geometric shapes used in Islamic crafts like architecture, ornamentation and carpets,calligraphy, etc. Therefore the study deals with the hidden qualities and characteristics of circle as well as its relation with higher systems.

\section{GEOMETRY IN ISLAMIC ART}

The History of Islamic art especially in architecture as the art of regulating space is an indication of a type of specific and special view of Muslim engineers, architects and artists into geometry and its application in sacred art. Geometry in Islamic art is dominant and outstanding ornamenting form that has always governed on other ornamenting traceries and

images. During history, Islamic and ornamenting arts tended to use geometric shapes and designs and rarely had eagerness to show sculptures and bodies based on Islam's instructions and the Holy Quran' principals. In fact, Muslims artists had recognized illustration of human body as a kind of idolatry, preventing themselves from copying it, and did not permit naturalism and mere imitation from nature. For this reason, expansion of a unique view in ornamenting art that be abstract and separated from nature and material have been appeared which do not completely follow the nature (Baharlu 2011:40).

The significant Tool of expression for Iranian architecture has always been geometrical material. He have used two kinds of geometry in his work: structural geometry and Euclidean shapes. Structural geometry has been the basis of formation of his monotheistic creation and Euclidean geometry has been the basis of formation of his plural creations. His geometry was an expression of regularity and rule that is governed on existence.

Geoetry has a close relation with fate in Islamic concepts and is a kind of recreation of divinity's fate and determination in arabesque architecture and geometrical images. In a word, engineer in Islamic art is recreator of images of imaginary world in two material and abstract aspects. Abstract aspect shows itself within abstract images and material aspect in form of architecture (Bolkhari 2006: 520$529)$.

\section{CENTRALISM IN ISLAMIC ART}

Centralism is hidden in geometrical regularity's concept. Being innovated and developed by Islamic ideology, Iranian's Islamic art, has shown many samples of centralism whether as symbolic or as realistic. One of the most conspicuous aspects of centralism in Islamic culture is Ka'aba House as Muslim's direction (Qibla) or attention center of all of Muslims. All of faiths introduce their own temple as earth and universe center symbolically (Burkhart 1967: 23). This issue is a moral and symbolic matter that is also applicable regarding Ka'aba generally. But it is only Kaaba that does also appear actually and in sense universe still as universe center. Most apparent eternal revelation in Islamic architecture is Kaaba and circular motions of Tavaaf(ritual spinning around $\mathrm{Ka}$ 'ba) around a square that have not been finished thousands of years depict most important sample of a living eternity.

Contrary to churches and temples that has a center where prayers face to it and in fact each one shows a specific center, Muslim's mosques do not have their own specific center and all of them have attention to a universal sole center (Kaaba) (Naghizadeh B 2005:104).

This aestethic and moral principal, has inspired Iranian Muslim artists to imply to this principal in their works somehow. One of aspects of this issue is application of words and subjects that are 
indicators of center concept in an apparent way, such as the word of square, which was explained. The other one is the word of pole that although maybe is called for two ends and extremes of a subject, but in wording of mystics intention of pole is a center which sense and lives are directed to it. One of another apparent symbols of this principal, is traceries of Iranian's carpet which are based on coordinates that are related to Islamic art, most of them depict a center as well.

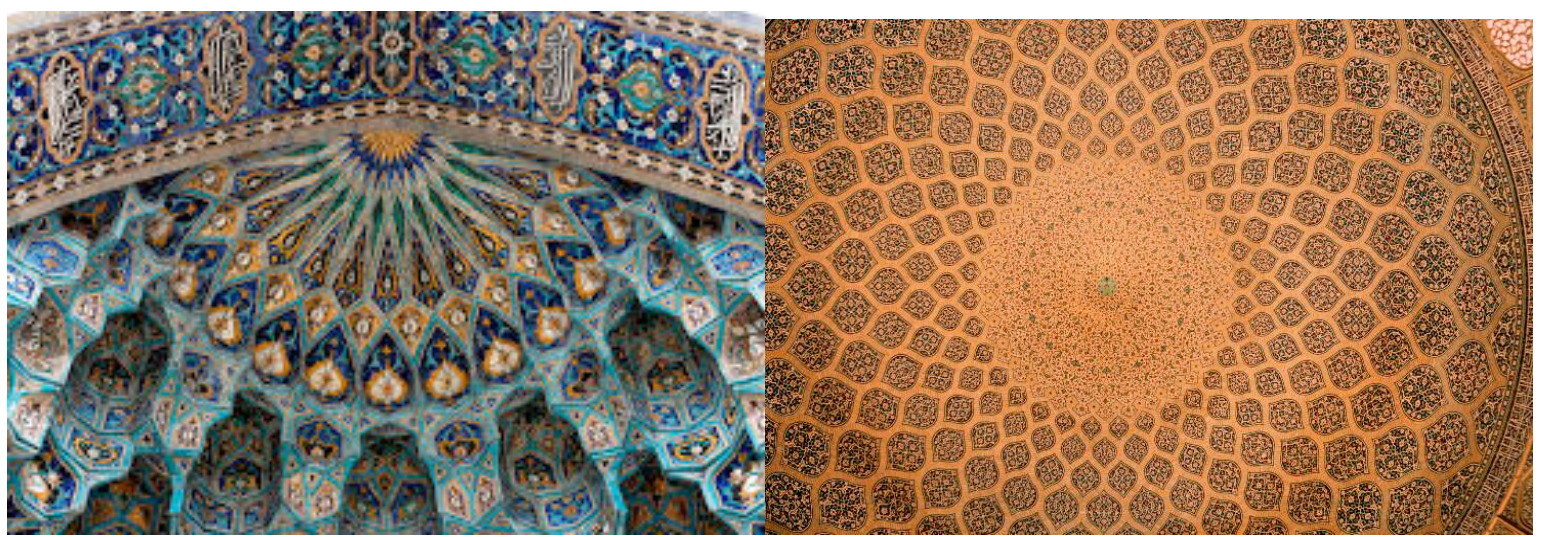

Fig 2,3:the under dome ceiling decoration and "Qibla wall" (altar) ornamentation on the basis of circle

There are other subjects that can indicate them as interpretation of centralism too. One of them is symmetry. Symmetry (especially in building's facades) is pointing to a center in sky. Music of leader in traditional sports and formation of crowd in mystics' Sama centered in a center and around a circle that its center is important. Many of their elements are also indicators of this thought in reality. Mosque's yard with devoting of its center to the water (fountain) reminds an aspect of importance and centrality of purity and perfect human. Also some elements such as domes (and especially special geometrical forms that are traced on them) has a unitary stress on center. A center that gives life using special geometrical forms that their center is tangible and important such as circle and square and reminds the human into its meanings.

The art of gardening that its symbolic aspect is apparent in traces of Iran's carpet is a clear and apparent example of centralism. Centralism is clearly conspicuous in an art that called Farsh (in contract of Arsh) and Farsh is a name for earth in Iran's culture. This is how in all of Iranian arts specially in poet and music and tracery there is a center that is formed around it, goes and returns and to each direction which face, again directs to that center:

\section{CIRCLE}

Each one of three main geometric shapes has their own specific characteristics and some characters and situations has been attributed to each one of them that was either due to their inherent shape or due to reaction of physiological-psychological system of human or due to specific cultural interpretations. 


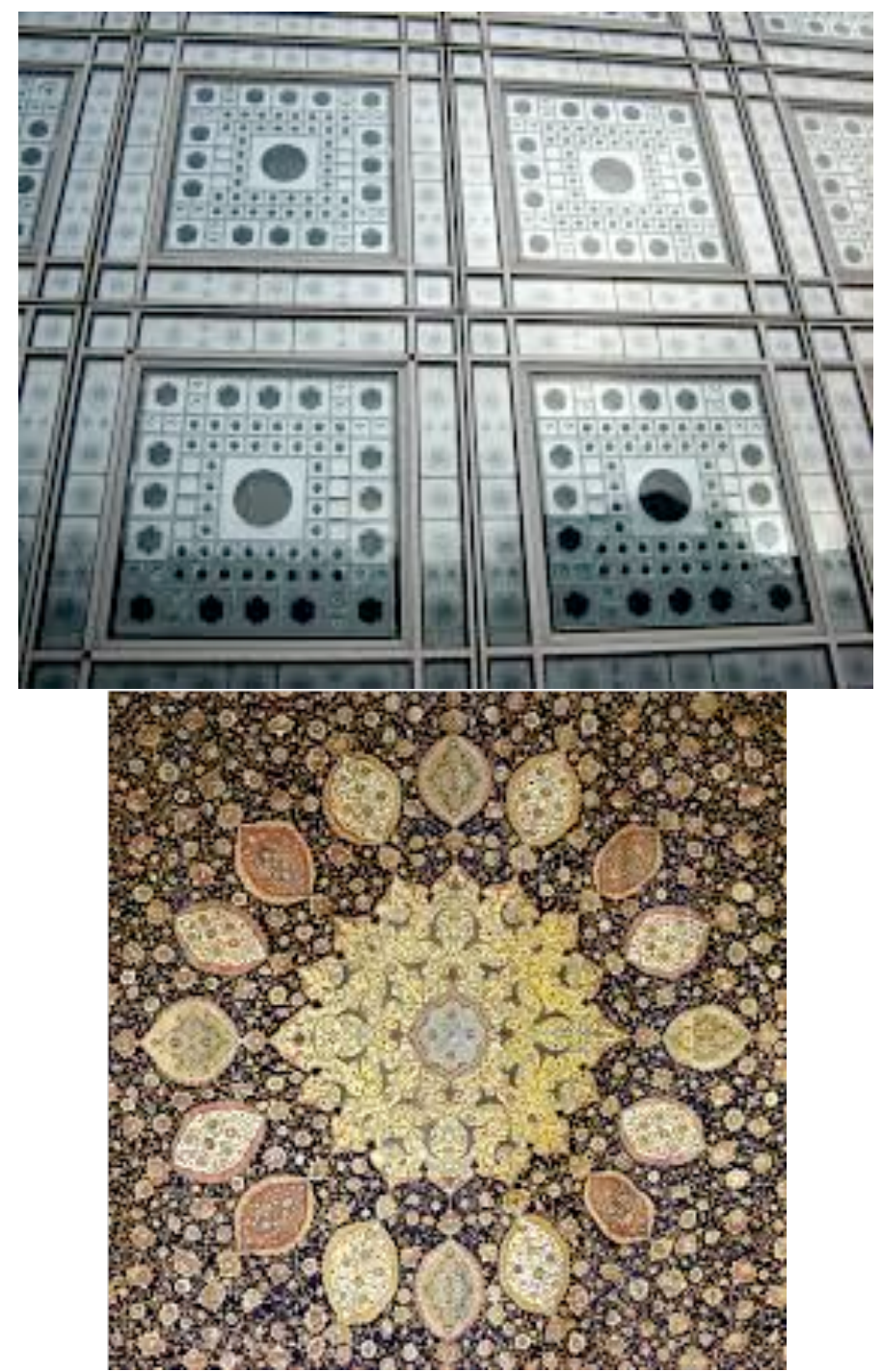

Fig4,5: The use of circle as the base of surface decoration in Islamic architecture

Circle is the symbol of perfection and simplicity and at the same condition most complete geometrical shape that is symmetrical relative to center from each direction. Circle has even value from all sides and this means that circle does not know any direction. Therefore, its stimulating combination is most simple type. Circle has neither start not end. Is an endless motion that always returns to its starting point (Gruter 1995:307).

Circle is the symbol of heavens, infinity and wholeness. Circle always has had a symbolic value and is a long lasting pattern in human mindset that shows some concepts such as holiness, perfection, infinity and eternity.

Plato knows circle as the most complete and beautiful shape. Shuan in expression of circle mystery writes: circle is an extended point. Radiuses of circle are radiation code, circumference of circle is reflection code and surface of whole circle is code of existence itself or a specific level of existence (Akbari 2011: 14).

Circle is most important coded form for imagination of unitary and integrity issue in constitution of existence universe. It should be noticed that no code and form for illustration of unity in multiplicity is better than chain of geographical designs that are surrounded by circle. 
Circle not only is perfect indicator of justice and equality in all of aspects in a limited field but also is most beautiful source of all polygonals that is considered as container and infrastructure of all of them, both.

Circle was an indicator of moral universe in human societies from old time. Moreover, curve and dome and also arches can be considered as indicators of praying human in two essential modes of genuflection and prostration that both of them are from pillars of pray (Naghizadeh 2009: 374).

\section{POSITION OF CIRCLE IN ARCHITECTURE}

philosophers of history have considered circle and sphere as most complete shapes. Sphere accepts less diversity relative to other shapes and pertain its form in each direction that has been placed. Hence, geographical shape of sphere is more general than all of geometrical shapes and contains the other shapes somehow and those shapes comes outside of sphere. This is why spherical shape is in form of universe's testis i.e. is indicator of all of possibilities that become appear in their primary and childish mode during a revelation period. While square that is indicator of stability and settlement has parallel tri surficial faces that is determined on axis's that forms coordination's system. And this is while three axis's that form three dimensional cross of coordination's system should be recognized as something that is drawn from center of a sphere who its infinite expansion fill the space and this issue make relation between sphere and square definite and in this regard what is inside internal and central sphere seems to form overturned of external part of square (Genon 1384: 162). Genon believes that direct use of circle as a symbol should be done conservatively and use it in its position and in a special way. Because its character of having no direction and multilateral dynamic give it some attributes which its use in architecture needs a lot of delicacy (Noghrekar 2009:472).

Commonly two kinds of usage of circle have been conventional in architecture:

A-Direct and raw usage of circle in architecture design

Vitrovious, first architecture theorist in 84 years before Christ, in book of ten books of architecture shows a human who laid and opened his hands and foots. In this situation fingers of his hands and foots become tangent to a circle that its center is his bellybutton. He concludes that if nature made the human body in a way that its members be proportional with his/her general shape, so oldies' opinion is also reasonable that elements of building should be constructed symmetrical and proportional with its general shape (Gruter 1375:307). Saaremi, knows Alberti as one of first samples of fully conscious and instructed thought and design that created a profound stream in architecture of end of $15^{\text {th }}$ century and beginning of $16^{\text {th }}$ century (same: 308 ).

However Alberti's hesitate between regular shapes and circle is due to his partial look to median centuries (beside to Roman architecture). It was Andre paladio after him who with more boldness declared in second part of fourth book from "four books in architecture" series that: we are looking for selection of the most complete and best shape in order to ornament our temples to it as a jewel. In addition, as it is shape of circle that is simple, uniform, even, strong and comprehensive among all of shapes, so we will build our temples circular. This shape will have god's elegancy, because is limited just to a line and its start and end is not appear. Start and end becomes as one here. This shape is comprises from elements that all are equal with each other and all are contributed in its creation with same level and finally most far points of these elements has equal distance from its center (Gruter 1375: 310). 


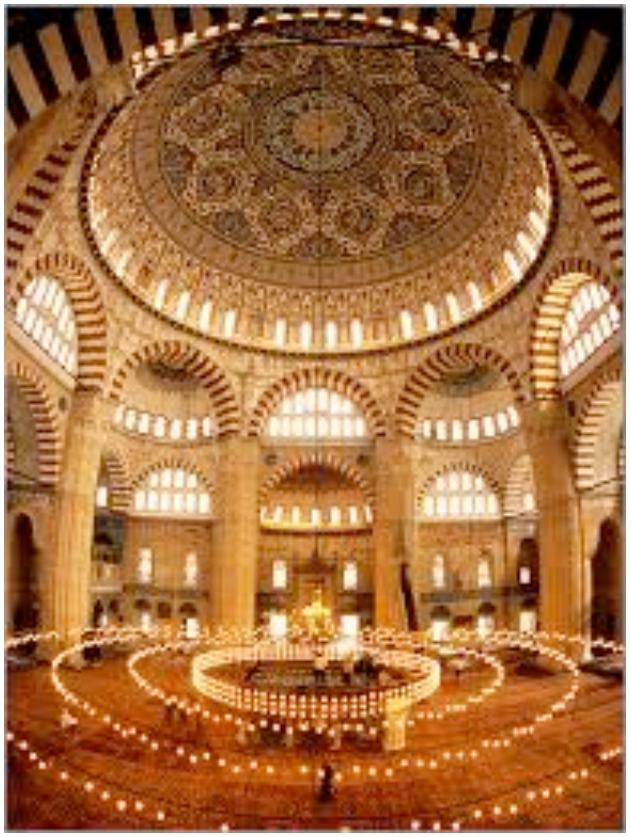

Fig 6:the circle based space arrangement in the architecture and decoration of mosques

If above discussions are mostly regarding temples and religious spaces, next architectures expanded this issue and attention into sphere and circle purely found a special form. Someone

became fully mesmerized by these shapes and someone put them away completely. From fisr group we can call Atin lui bule, France revolutionary architecture, who made many efforts to use pure and instructed forms, he says about sphere and its characters in architecture: "sphere is a symbol of perfection, extreme limit of symmetry, most complete type of regularity and highest diversity from each aspect. All are gathered in a sphere. Has simplest form and its outer lines are pleasant and is most talented to play with light" (same, 317). Bule's designs shows his attraction to sphere clearly. In Gruter's belief “ it was not just Bule who became so fascinated to sphere, after revolutions, whether France revolution and Russia revolution, during revolution's flourish and expansion, sphere have found a fully prominent role in architecture's aesthetics" (same: 318).

There are also some critics in front of these extremes. Such as Lokoreboz, who himself considered sphere among basic volumes, due to some special attributes in it, recognized its usage in architecture inappropriate and called it a "anti-architecture" form. Because sphere does not make a good relation with earth as basis (same: 319). Maybe it was due to these kinds of critics that architectures be more conservative to use circle directly.

Right in his works diminished circle's forms down to decorating elements gradually and this is an important issue (same, 312). But this raw usage was not just in west architecture. East architecture, even from old era, also have many samples of circular temples that were used often based on sky mystery.

B-usage of base circle in organizing Base circle is used in many traditional space organization methods. By Genon's word: "circle can be known as origin and testicle of everything in universe. Everything in commence mode starts with circle and it can be said that circle is mother of all shapes and includes all of designs inside itself "(Genon 1365: 158). Burkhart in this respect says: " proportions in traditional organization is based on dividing of circle by regular shapes that are drawn tangent to it and inside it so all of dimensions of a building obtained from circle that is clear code of existence's unitary and contains all of existence's capabilities “ (Burkhart 1349: 19).

However, this issue is not specific for Islamic tradition and west and east civilization have shown attention to circle and derivation of geometry from it in many eras. In east's art and architecture, 
Mandala that Ardalan called it as Mandel is one of most important evidences of it. Mandala is a Sanskrit word that means circle. In east art Mandala's usually are used accompanying with a square that is born inside them and why not if that square shape is considered many times as Mandala solely (Zekrgu 1378: 383).

Most usage of Mandala is appeared in art of architecture and urban development. In wise book of "Watro shastra" that was considered the instruction book of architectures for construction of praying places, a specific instruction is provided for creation of geometrical pattern of building that this work starts with drawing of circles and ends with a square and this trend is a symbol of sky fall on the earth. Circle and square are two complete shapes that first one (circle) is a symbol of sky and its infinity and the second one (square)-at the same time of perfection- is indicator of the earth, material universe and its limitations. As circle has no specific edge and border, shape wise, looks endless, like sky. In contrast, square has specific edge and border and has end. Its start, end and extremes is clear. It means that it starts from somewhere and ends to somewhere. Hence, it is said that square is symbol of soil universe or earth and motion from square toward circle is motion from material universe toward meaning's universe. So motion from circle to square in construction of temples is a symbol of providing earthly preparations for appearance of spiritual insensible infinity in its sensible earthly form i.e. temple (same: 388). Zekrgu eventually shows appearance of Mandala's in Islamic architecture that their most important one is Kaaba and circular motions of Tavaf around a square that is not cutted thousands of years shows most important sample of an alive Mandala (same, 390).

But this issue was a matter of attention in west tradition too and stress on derivation of geometry from circle is fully clear in works of someone such as Alberti beside Genon and Burkhart. They also introduced this tradition because of familiarity with European tradition and even Islamic civilization through renaissance years. One of good investigations that was done in west on geometry in architecture of median centuries is Ernest musel's work. Title of its thesis was "circular geometry" and showed derivation of types pf geometry from circle in architecture of median centuries (Rob crier 1380: 15). Crier brought a short report of his work in his own book but does not have so tendency to it and quickly goes to sacred book of new architecture i.e. the book of :Modular" of Lokoreboz and pursue studies on human body. But for more accurate expression of constitution and organization of geometry derivation from circle in Islamic art and architecture and its difference with other western and eastern traditions multiple investigations have been done that as most important ones of them we can imply to works of Esaam alsaeed, deceased Pakravan, Eng. Kambiz navayee and Eng. Kambiz hajghasemi and Eng. Molavi. Most of these researches try to analyze geometric drawing structures that had been formed based on dividing of circle in traditional societies.

\section{CIRCLE'S POSITION IN ISLAMIC ARCHITECTURE:}

Among Muslim architectures, circle and sphere are used to start and end organizing of the space and role of these two elements often had a hidden aspect. In this way that start of work was with drawing of base circle and architecture's design were appeared from that circle and eventually design went upside vertically and at the end arrived to a new circle again. Generally most important characteristic of application of circle and sphere in Islamic civilization especially in horizontal sections of architecture is its essential and fundamental and at the same time hidden and invisible aspect in creating of architectural design. However, in sections that make a relation between earth and sky, matter is totally different and a very pleasing combination of square and sphere can be found in four vaulted fire chamber corresponding to combination of earth and sky (Noghrekar 2009: 473).

Geometry of Iranian architecture especially in religious buildings is connected to mystical concepts in minds of We as Iranians. But these concepts are unknown and unacceptable for many of western scholars and theorists.

In Islam, circular shape is known as sole shape that is able to express divinity's elegance. Often a building where has circular shape and a cubic base imagines sky and earth duality (Ahmadi maleki 1377: 22). Dome that is one of main elements in Islamic architecture is one of most important mythical symbols in Islam world, both in color and shape. Geometry of dome is indicator of existence 
circle and also love circle. Repetition is not boring here. Here should always be wanderer in love circle.. Here we reach to unitary from repeats. Because each one of units are stepping toward their original distinct and as get closer to it, be merged to each other more and however there is no matter of mere repeat. Forms are divided into multiple groups of different shapes that each one is indicator of level and position of a section of brick and adobe society that is placed in interaction with other sections and it is dependent to them and they are dependent to it. And although the role of someone is more than the others in remaining of the roof on four wall, it is impossible to know each of them better than the others. Excellency's indicator of each one is dependent to its piety that is obeying from governing geometrical regularity (Naderifar and Ahmadi 1389: 43).

In Islamic architecture, it is only building drawing of domical roofs that has concentric drawing which play role as code of solidarity between sky and earth or descending place of divinity's bless. Also special shape of dome that imagine "Mina dome" or sky is indicator of comprising of all creation itself (by sky) and this point has coincidence with this concept that circle is symbol of totality and perfection (Bolkhari 2006: 513).

Dome is symbol of sky and essentially due to its curve is considered as sign of soul and abstracts universe. Basically imagination of abstracts in form of straight and angular lines do not come to mind of nobody and when their imagination they come to the mind or appear in material universe in form of curvy lines and spherical volumes.

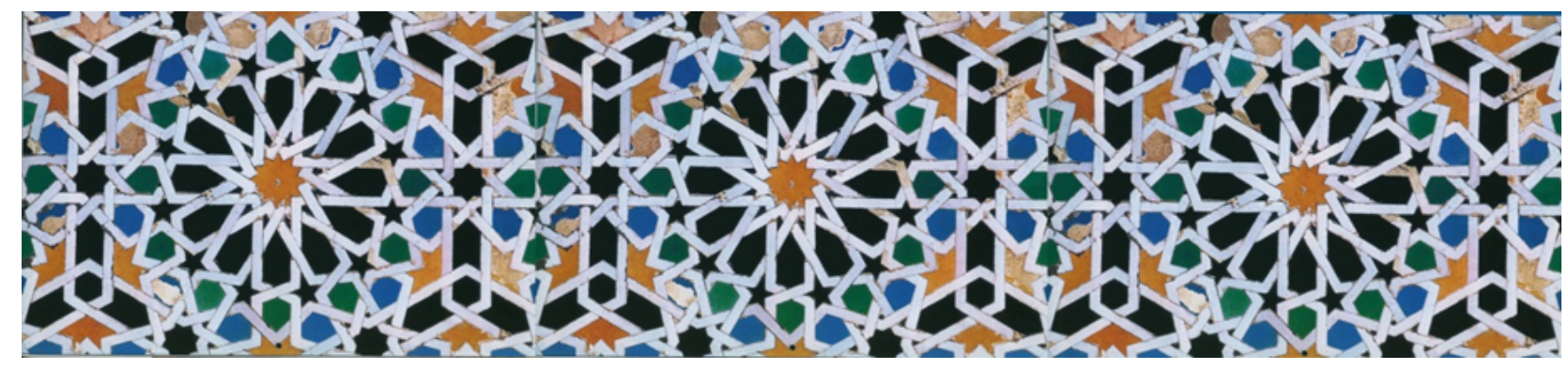

POSITION OF CIRCLE IN ORNAMENTATIONS OF ISLAMIC ARCHITECTURE:

Ornamentation is an inseparable part of art and architecture of ancient world and ornamenting element is meanings conveyor. Domination of ornamenting aspect can call as main and all time attribute of Iranian art that has remained consistent from prehistory era up to now and is indicator of determined ornamenting ideas (Kharazmi and Afhami 2001).

Islamic ornamentations have not been separated from Islamic art and has a main role. Surface ornamentation is one of geometry focused and basic aspects of Islamic decoration that Muslim artist has used it for creating of diversity, escape from uniformness while creating of integrity. Ornamenting elements is limited to decorative handwriting and organic-geometric arabesque and scroll works, but their multiplication on flat and curvy surfaces depicts a peerless image. Although Muslim artists have not been so innovative in terms of selection of shapes but has many originality in surfaces ornamentation (Ernest Grube 2001: 161).

Islamic ornamentations covers subjects and buildings as a cloak and its most important logic is creating of unity and relationship of all of elements with each other. Islam-based ornamenting principals is implemented based on a logic in different eras and for types of buildings in different fields including architecture, textiles, terra cotta's, woodwork, metalwork, book' ornamentation(calligraphy) in required scales. These ornamentations has capability to be expanded or contracted in different parts (Ernest Grube 2001: 144).

Generating source of Islamic design is circle. Islamic ornamental pattern is built from a regular figure inscribed in a circle, which is then repeated infinitely across the surface. All the while the circle continuous to guide the pattern, but its rather felt than seen. In Islamic ornamentations, circle shape is 
used as an element for generating of abstract traceries and creating of intricate diversified patterns based on repetition and symmetry. Circle-based designs such as arabesque, flowering shrup, embroidery,... are used for geometrical surface workings in one or multiple levels. By successive calculated dividing, squares, triangles or polygonal can be placed inside circles. These shapes with rotation and symmetrical embellishments be multiplied and divided into finer elements. This repetition and continuous displacement of designs on surfaces of objects and buildings has capability to be multiplied infinitely that is interpreted as symbol of god's presence in everywhere (Ernest Grube 2001: 161).

In whole ornamental complex of Islamic architecture some general and fundamental principals is appeared. First principal is being timeless and no where of traceries and repetition of design in different scales. Each trace is a partial part of whole surface's pattern and is obtained by mutual effect and super positioning of types of designs and different symbols and each one of them pertains their entity inside composition. One of another attributes is expansion or reduction of capability of each trace and their capability to be repeated infinitely in a symmetrical form (Ernest Grube 2001: 163).

Islamic ornamental traceries are a helix that with motion-full rotation around multiple centers of symmetry, acts like attractive magnets that does not leave a place for accurate looking so each time that eye is fruitlessly trying to stabilize itself to these intricate geometrical shapes or analyze their hidden background designs, will result in to emerging of new trace itself. Designs of polygonal star with their motion-full and restless geometrical shapes, that if look at it from each side it converts to another continuously, seems to violate the principal of constant look of viewer and drawing his attention into an image inside frame (that is basis of perspective of renaissance era) (Bolkhari 2006: $567)$.

Ornamentation in Islamic architecture is not limited to cover surfaces but also by proper taking advantage of enticing visual effects helps intangibly that space transfer from one surface to another be done continuously and eventually enriches visual understanding of viewer more and leads to calm (Ernest Grube 2001: 162).

Arabesque is one of circle-based ornamental elements in Islamic architecture. Sole tool of Muslim artist in imaging of existence's beauty by imitation of imaging by god and also creation of images and symbols of high universes is usage of arabesque geometry and traceries.

The abstract ornamental strips created by Muslim masters by using spiral and interconnected Hellenistic shapes on mathematical basis.

These designs surrounds whole surface in symmetric directions and has flexibility and bending capability in different directions. In this way that trace of a stem expands on surfaces and multiplied regularly and gives leave and branch. Arabesque does not fill all of the surface instead is like images in space that placed protruding on a background. That their colors are often representative of concept of space continuity. Like some circles of water on face of dock which expands in unit and multiple magnitudes. Arabesque helical stems that like celestial trees flourishes with relying on symmetrical axis is an imagination of heaven and other hand presence and appearance of arabesque on different surfaces was not just for ornamentation, but in addition to supply aesthetical targets was indicator of high concepts.

Symbolic repetition of arabesque was a kind of reminding for human to always remember releasing from down universe and flying to heaven and toward god. On the other word, repetition is pray. On the other hand using of this kind of abstract images and amenity of helical plant species is reminder of promised heaven for believers in Quran and Islamic quotes. From moral and material perspective, characteristic of motion of helical curve or arabesque is tending to unity and perfectionist meaning (Pourjafar 1381:3).

From Titus Burkhart opinion, great Muslim cognoscente, arabesque traceries are symbolic faces for alight veils: "the walls of some mosques that is covered by enameled tiles or a branch of delicate 
arabesques of stucco is reminder of mystery of veil"; based on prophet quote: god is hidden behind seventy thousand veils of light and dark and if those veils fall god's look on anybody and anything that be directed its shine and brightness and eruption will burn all. Veils are from light to hide divinity's darkness and are from darkness to be veil of divinity's light (Bolkhari 1384: 236).

\section{CONCLUSION}

Islamic art is think calming art and geometry of Iranian architecture especially in religious buildings is connected to mystical concepts. Hence, practical look to geometry as a powerful tool in founding of Islamic architecture cannot be separate from semantic look. Circle also that is one of most important geometrical shapes and birth source of Islamic architecture elements not only had a considerable and undeniable role in formation and expression of profound practical concepts whether from visual aspect or from space understanding aspect and visual effects, but also always provide conditions for to notify addressee toward center and birth point of universe that is highness divinity's existence. Hope that through familiarity with inherent unique capabilities of circle and its other geographical forms, i.e. sphere, ring and arch, somehow a proper field is being provided for the sake of targeted and wakeful usage of it by architects in architectural designs.

\section{REFERENCES:}

Ahmadi Maleki, Rahman, (1999), symbolic forms and traceries in Iran's mosques, eternal heritage, sixth year, 2 edition

Akbari, Fatemeh, (2011), Spiritual cognitions and geometrical codes, the research journal of Farsi language and literature, $4^{\text {th }}$ year, $1^{\text {st }}$ edition

Ardalan Nader and Laleh Bakhtiar, (2002), Sense of unity, Tehran, Khaak publication

Baharlu Alireza, (Bi ta), the role of computer in design and drawing of geometrical traceries Zilij in wooden ornamentations and engravings, the book of Mahe Honar, 15 edition

Bolkhari, Hassan, (2006), fundamentals of Islamic art and architecture, Tehran, Mehr Sure

Genon, Rene, translated by Ali Mohammad Kardan, (2006), siege of quantity and emblems of end of the world, Tehran, center of university's publications

Gruter, Yurg, translated by Jahanshah Pakzad, (1997), beauty of aesthetic in architecture, Tehran, Shahid Beheshti University

Krichlu, Kate, translated by Seyed Hassan Azarkar, (2011), analysis of ideological concepts of Islamic traceries, Tehran, Hekmat publications

Plato, translated by Mohammad Hasan Lotfi and Reza Kaviani, (2002), the era of Plato's works, Tehran, Kharazmi

Plato, translated by Mohammad Hasan Lotfi, (1975), Plato's republic, Tehran, Avicenna

Grube, Ernest, translated by Yagub Azhand, (2001), architecture of Islam world, Tehran, Molana publications

Naghizadeh, Mohammad, (2007), Islamic architecture and urban development, Isfahan, Rahian publications

Naghizadeh, Mohammad, (2007), fundamentals of religious art and Islamic culture, Isfahan, Rahian publications

Naghizadeh, Mohammad, (2007), city and Islamic architecture, Isfahan, Mani publications

Naderifar, Hamidreza and Solmaz Ahmadi, (2011), meaning oriented geometry and its emerging in Islamic art's structures, The book of Mahe Honar, 146 edition Pourjafar, Mohammadreza and Ashraf Mousavilar, (2003), assessment of attributes of rotational motion of helix (arabesque, the symbol of sacred, unity and beauty), the scientific and research seasonal journal of Alzahra University, 12 year, 43 edition

Zekrgu, Amirhossein, 2009), a contemplation on Kumara Suami's opinions, the letter of science cultural hall, 14 and 15 editions 